\title{
France re-focuses nuclear research body . . .
}

Paris. France's Atomic Energy Commission (CEA) last week signed a four-year contract with the government formally endorsing the commission's withdrawal from state-funded participation in the development of new industrial technologies - an initiative actively promoted by previous governments - and its renewed focus on long-term research, particularly that relevant to the nuclear industry.

The government intends to establish these contracts with all state-funded research organizations, defining both their objectives and the means to achieve them, as part of the development of a national research strategy. It signed the first contract earlier this year with the computing agency INRIA.

The new contract between CEA and the government ends a decade of uncertainty about the role of the commission in French research, given the decreased research needs of the nuclear industry. "Our role in meeting the research priorities fixed by the government is now completely clarified," says Yannick d'Escatha, deputy chairman of CEA, who adds that guaranteed funding levels for the four years of the contract will provide welcome stability.

The contract was signed by the ministers for higher education, industry and finance, and reaffirms nuclear research as the CEA's major activity. But it adds that the commis- sion should act as a supplier to meet the demands of its customers, namely the state, the nuclear industry and small and mediumsized companies in nuclear and other hightechnology fields.

The contract also formally endorses the commission's role in other areas where it has acquired competence, such as integrated circuits and particle physics. For example, under a national strategy for life sciences due to be announced this week, CEA is expected to be given responsibility for coordinating radiobiology research among all state-funded bodies. It is also leading European efforts to build the superconducting magnets for the planned Large Hadron Collider (LHC).

Under the terms of the new contract, state funding for CEA's civil activities FF6.2 billion (US $\$ 1.23$ billion) this year will increase at the rate of inflation. This provides protection against budget cuts. But it also means that the CEA will either have to turn to industrial contracts, or sell some of the shares it holds in nuclear companies, if it is to find the money for a ten-year plan to boost investment in large research equipment, says deputy chairman d'Escatha.

The research priorities listed in the contract were hammered out during two years of negotiations between the government and $\mathrm{CEA}$, and followed an extensive internal restructuring of the commission (see Nature
368, 6; 1993). Fields earmarked for increased support include research into the safety and performance of the next generation of fission reactors, funding for which will rise by 60 per cent during the four years of the contract.

The FF350 million that CEA now spends annually on research into the use of plutonium fuel will also increase significantly, with funding of research on mixed uranium/plutonium (MOX) fuel increasing by 80 per cent, and that on the incineration of excess plutonium stocks by 50 per cent. While current reactors can only burn 30 per cent MOX, future reactors will use the fuel at full strength, says d'Escatha.

Research on the separation and incineration of waste will also be increased by 50 per cent from FF650 million, while funding of the laser enrichment of uranium will be maintained at FF450 million a year. "We can't be behind in this area", says d'Escatha.

CEA will find the money for these priorities by withdrawing from all state-funded participation in industrial activities, and by reducing staff numbers. These have fallen from 23,000 to 18,000 over the past five years, and may fall by as much again. CEA says it hopes to avoid redundancies, perhaps by keeping recruitment rates lower than retirement levels. The government has said it will also transfer some CEA staff to universities.

Declan Butler

\section{Research reactors may give Scottish reprocessing plant}

Munich. The US Department and the UK Atomic Energy Authority (UKAEA) have been discussing the possiblility of reprocessing in Britain highly enriched uranium (HEU) provided to non-US research reactors. The discussions suggest that the United States may be prepared to relax its strict policy requiring fuel rods containing $\mathrm{HEU}$ to be returned.

In particular, the United States has expressed interest in using the UKAEA's nuclear reprocessing plant at Dounreay, in the north of Scotland. Such a move could avoid the threatened closure of Dounreay's reprocessing plant, known as D1204, and provide it with ten more years of life.

Even if no such agreement is reached, the European Atomic Energy Agency (Euratom) and representatives of several European research reactors are already negotiating directly with Dounreay about reprocessing spent fuel rods, fearing that the United States may not be able to fulfil a previous promise to take them back.

As part of a 1978 agreement designed to stop commercial trading in weapons-grade uranium, the United States promised in 1978 to take back spent fuel rods of US origin from foreign research reactors if the lat- ter agreed to convert from low-enriched uranium (LEU) to HEU, despite the relatively high costs of conversion.

Last year, however, the first such shipment of fuel was initially refused entry into South Carolina, where it was intended to be stored at the Savannah River site, because of local protests (see Nature 371, 192; 1994).

The remaining waste - an estimated 15,000 spent fuel rods - is stretching dangerously the capacity of some research reactors' own storage facilities, but cannot be shipped to the United States until the Department of Energy (DoE) has completed a full environmental impact statement.

Under US law, such a statement must present all the possible options for handling the waste. One would be for Dounreay to reprocess at least some of the spent fuel. But under the 1978 agreement that could be done only if certain conditions were met.

First, the Dounreay plant would have to convert any HEU fuel it receives to LEU. Second it would have to refuse to handle fuel from reactors that are not willing to change over to LEU. Finally, it would have to agree to build an LEU reprocessing plant to encourage reactor conversion.

The talks between the US State Depart-

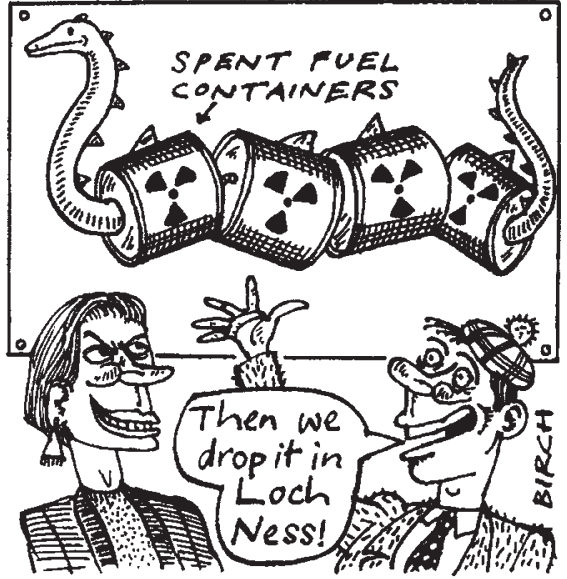

ment and the UKAEA have so far been inconclusive. The United States has been trying to persuade Dounreay to accept its conditions, arguing that an agreement could save the plant from closure. The UKAEA is said to be less than enthusiastic. But an official says that "if there is sufficient customer interest" it would consider building facilities to reprocess advanced LEU fuels.

The US National Control Institute (NCI), an independent group that monitors potential breaches of the 1978 agreement, is 


\section{. . . as UK agency cuts staff to prepare for privatization}

London. Plans by the British government to privatize AEA Technology, the science and engineering division of the United Kingdom Atomic Energy Authority (UKAEA), took the next step forward last week with the publication of the Atomic Energy Authority Bill.

No decisions have been taken on the precise form that the privatization will take. "The bill deliberately leaves a number of options open so that we can make decisions nearer the time of sale," says Richard Page, the parliamentary under secretary of state at the Department of Trade and Industry.

In welcoming the bill, Sir Anthony Cleaver, the chief executive of AEA Technology said it will give the company freedom to expand its commercial activities.

But the move is being disputed by labour unions representing UKAEA staff, because they say it will lead to further cuts in research and technical staff that have already dramatically reduced the scientific capabilities of what has been Britain's main nuclear research and development organization since 1954.

Last year, the UKAEA, was formerly split into two as part of a long-promised privatization strategy. The UKAEA Government Division, will remain a government authority for nuclear facilities. The other, AEA

\section{new lease of life}

opposed to any reprocessing at Dounreay on the grounds that allowing reprocessing outside the United States would weaken its anti-proliferation policy.

But the talks are far from any likely action. The DoE will include the "Dounreay option" in its environmental impact statement. But it will not necessarily be accepted as the preferred option for dealing with $\mathrm{HEU}$ waste from research reactors. Even if agreement on reprocessing is reached with Dounreay, it is unlikely to take effect until 1996, by when various research reactors may have found solutions of their own.

Indeed, some reactors have now started talking to Dounreay independently about reprocessing their spent HEU fuel as they already have acute storage problems, and may be unable wait for the United States to make a firm decision. Dounreay has been encouraging such discussions because its D1204 plant, previously used for handling waste from fast breeder reactors, is threatened with decommissioning because of a lack of contracts.

The DoE wants to prevent the research reactors from negotiating directly with the UKAEA, without meeting its own conditions.

Alison Abbott
Technology, is being spun off as a general science and engineering service business. It now has an annual turnover of $£ 250$ million (US $\$ 406$ million), and made a profit of $£ 10$ million last year but only about half of its revenue comes from the nuclear industry through competitive tendering for decommissioning and safety contracts. The rest comes from general high technology consultancy and development work.

The government division holds approximately $£ 8$ billion of assets, which include nuclear and other facilities at Dounreay, Windscale, Risley, Harwell, Culham and Winfrith. It will remain responsible for sites, nuclear facilities, and awarding decommissioning contracts to companies including AEA Technology.

Nuclear research will not disappear completely. The agency still provides between $£ 12$ and $£ 13$ million a year for fusion research at Culham, for example, and works closely with the Joint European Torus project. But when this is compared with budgets of around $£ 200$ million in the late eighties, it is obvious some research has "fallen through the cracks" says Dr Derek Pooley, chief executive of the government division.

The British government argues that as the nuclear industry is now fully mature, research funding should be allocated on strictly commercial principles. "There are very strong differences of opinion whether what we have done in Britian is right or not," says Pooley.

But labour unions such as the Institute of Professionals, Managers and Scientists (IPMS) claim that moves to privatize AEA Technology undermines long-term planning in the industry. "We do not agree that the market should determine the research because it is very difficult to plan any longer than a few years," says Tony Wickett, Branch Secretary for IPMS.

Nick Parsons, head of media relations for AEA Technology, says the company's research budget is comparable to that of its competitors, five per cent of its annual turnover, or about $£ 12.5$ million.

The union is concerned about the other effect of government and the nuclear industry reducing research spend, namely staff numbers have been reduced since the 1980 s from 14,000 to a total of just over 7000 . The government division is not expecting any more redundancies but AEA Technology admits it is seeking $300-400$ redundancies before the start of the next financial year (1 April 1995). "It is always a matter of regret but the only future for our business and staff is if we can be competitive," says Parsons. "It is essential to our survival, whether or not we are privatized."

Fiona Gammie

\section{Russia links higher science funding to structural reforms}

Moscow. The Russian cabinet has agreed to set up a new, streamlined Commission on Science Policy, headed by the prime minister, Viktor Chernomyrdin. The 20-member commission will be responsible for identifying research priorities.

The decision was taken a week after President Boris Yeltsin, in his annual address to the Russian Parliament, had admitted that public funds allocated to science "are insufficient to maintain the current level and amount of fundamental research".

\section{IMAGE \\ UNAVAILABLE FOR COPYRIGHT REASONS}

Yeltsin: research budget 'insufficient'. He urged a "structural reform of the whole scientific community".

In an subsequent address to the cabinet, the Minister for Science and Technology Policy, Boris Saltykov, emphasized that the government has cut funding for science by 80 per cent over the past four years, leading to a drop of onethird in the number of scientists employed.

In some fields, he said, the losses are irreparable. But one of the key reasons for the current crisis was the delay in implementing structural reforms. Although promising to increasing funding to three per cent of the total federal budget in 1996, he said that this should be accompanied by the closure of certain research centres, and greater efforts by the research community to adapt to the conditions of the market.

Indeed, the day after the cabinet meeting, the state Duma (parliament), in discussing the 1995 budget for the third time, agreed to approve a significant increase in funding of science. Their decision took the form of an amendment proposing to raise the research budget by a further 1,700 billion rubles from its current planned level of 5,400 billion rubles (US $\$ 1.17$ billion) - and to take this money out of government administration.

But Saltykov subsequently dismissed the proposal as a "crazy idea". Andrei Zakharov, head of the office responsible for the Committee for Education, Culture and Science, expressed his "horror" at the Duma's move. "Naturally I want Russian science to be healthy - but not at the price of destroying the state machine."

The state Duma is expected to take a final vote on the research budget tomorrow (10 March). It is widely expected to reject the calls for an extra 1,700 billion rubles but to approve an increase of 300 billion rubles on the figures proposed by the government.

Carl Levitin 